\title{
SOBRE AS AFINIDADES ENTRE A FILOSOFIA DE FRANCIS BACON E O CETICISMO
}

\author{
Luiz A. A. Eva* \\ luizeva@ufpr.br
}

RESUMO Este texto se ocupa de um exame, em caráter introdutório, das relações entre a reflexão de Bacon acerca das limitações de nossas faculdades e o ceticismo filosófico - um tema pouco considerado pela literatura mais recente, a despeito das muitas referências a tal filosofia. Ainda que, à primeira vista, tais referências possam parecer vagas e imprecisas, pensamos que um exame adequado de algumas delas pode revelar, não apenas a importância do tema para a compreensão de aspectos do seu próprio empreendimento, mas o interesse de Bacon pela literatura cética contemporânea. As peculiaridades de sua própria interpretação, por sua vez, parecem antecipar traços do modo como essa filosofia foi compreendida por filósofos posteriores, como Hume.

Palavras-chave Bacon, Ceticismo, Ídolos, Empirismo, Montaigne, Descartes

ABSTRACT This text focuses, in a preliminary way, on the relations between Francis Bacon's reflections on the limits of our cognitive faculties and philosophical skepticism, a theme not much considered by most of recent commentaries, in spite of Bacon's own explicit and numerous allusions to this philosophy. Even if these allusions seem at first sight somewhat loose and not very sharp, some of them reveal, we think, not only its relevance for understanding of some aspects of his own enterprise, but also Bacon's attention to the skeptical literature produced on the period. Moreover, the particularities of his own interpretation of skepticism seem to anticipate important features of the way this philosophy was understood by later philosophers as Hume.

Keywords Bacon, Skepticism, Idols, Empiricism, Montaigne, Descartes

* Doutor em Filosofia, professor da Universidade Federal do Paraná e pesquisador do CNPq. Artigo recebido em ago./05 e aprovado em jan./06. 
Como diz Michel Malherbe, em sua edição da versão francesa do Novum organum, essa obra de Bacon, ora celebrada, ora desprezada, foi sempre pouco lida. Embora se refira à sua fortuna na França, sua observação é pertinente num sentido bem mais geral, a despeito de alguns dos mais importantes filósofos modernos terem recorrido a esse autor para definir o sentido de seus próprios empreendimentos. Hume refere-se a Bacon como pai da física experimental e apresenta sua Ciência da natureza humana como um esforço de dar continuidade à obra por ele iniciada e continuada por outros moralistas britânicos, ao converterem a experiência no único fundamento sólido para a reflexão. ${ }^{1} \mathrm{E}$ Kant escolheu como epígrafe da Crítica da razão pura uma passagem do prefácio da Magna instauratio, em que Bacon se apresenta como aquele que, em lugar de inaugurar uma nova seita, pretendeu lançar os fundamentos de uma obra coletiva, capaz de dar cabo de um erro infinito. ${ }^{2}$

Porém - e esperamos aqui não cometer uma injustiça ou um exagero nem mesmo a relativa escassez de estudos sobre a filosofia baconiana nos parece justificar a carência nas abordagens das suas relações com o ceticismo filosófico. Conhecemos apenas um artigo, aliás bastante recente, inteiramente dedicado a esse tema ${ }^{3}$; e os comentários clássicos ao longo do século XX a ele não fazem mais do que menções passageiras ou genéricas, apesar de Bacon se referir ao ceticismo e aos partidários da acatalepsia com freqüência ao longo de toda sua obra, desde escritos mais antigos, como The praise of knowledge (1592), até as obras de maturidade, como o Novum organum (1620). ${ }^{4}$ Levando-se em conta que os comentadores muitas vezes se concentraram no exame das conexões do pensamento de Bacon com tradições intelectuais do Renascimento - como Lisa Jardine, que se ocupou da dialética, ou Paolo Rossi, que focalizou, dentre outros pontos, sua relação com a chamada "magia natural" 5 - , a lacuna se torna ainda mais relevante a partir dos trabalhos de Charles Schmitt e Richard Popkin, que nos propiciaram uma visão mais clara

1 HUME, 2001, p. 22, 684. Cabe confrontar esse prefácio com o aforismo I, § 80, do Novum organum, onde Bacon anuncia que um novo vínculo entre a filosofia natural e as ciências particulares seria virtualmente capaz de aportar progresso e profundidade não apenas às artes mecânicas e à medicina, mas também às "ciências lógicas" e à "filosofia moral e civil". As referências ao Novum organum indicarão, primeiramente, o livro, em seguida, o número do aforismo (§), e, por fim, quando necessário, a paginação relativa ao primeiro volume do The works of Francis Bacon, edição referida na bibliografia. Todas as citações referentes a essa edição das obras de Bacon virão precedidas da abreviatura "Sp.".

2 KANT, 1980, p. 721. A epígrafe foi incluída na segunda edição da obra.

3 Cf. GRANADA. A avaliação por ele apresentada do estado de arte desse problema não é diversa da que oferecemos aqui. Agradecemos à gentileza do autor em nos permitir a consulta de uma versão preliminar de seu artigo ainda inédito.

4 Outras obras em que se faz explicitamente alusão ao ceticismo são: Valerius terminus, 1603; The advancement of learning, 1605; Temporis partus masculus [depois de 1605]; Scala intelectus [antes de 1612]; De augmentis scientiarum, 1623. JARDINE, 1974; ROSSI, 1968; GRANADA. 
de como as tradições céticas do Renascimento, em suas vertentes acadêmica e pirrônica, contribuíram, numa dimensão até então ignorada, para a constituição do pensamento moderno. ${ }^{1}$ É bem verdade que Popkin, na sua obra clássica, menciona Bacon como propositor de uma espécie de "ceticismo parcial ou temporário", embora entenda que não se trata aí de um cético, e sim, a seu ver, do protagonista de uma estratégia "aristotélica" de resposta ao ceticismo. Mas são igualmente alusões de passagem, que não se desenvolvem no sentido de um exame mais detalhado de como teria ele compreendido e equacionado a problemática cética em sua reflexão pessoal. ${ }^{2}$ Todavia, mesmo que o caso de Bacon ofereça dificuldades na determinação das fontes de que ele teria se valido, parece-nos haver elementos disponíveis para sustentar que o ceticismo desempenhou, na sua reflexão filosófica, um papel mais relevante do que aquele que se tem usualmente reconhecido.

Não nos ocuparemos aqui de um exame detalhado sobre se os aspectos pertinentes da filosofia baconiana correspondem ou não à maneira precisa como os céticos formularam suas argumentações dubitativas, nem mesmo de um exame acerca do modo como ele pretendeu responder à problemática cética. Antes disso, parece-nos importante examinar em que medida se pode avaliar a relevância filosófica das afinidades que Bacon reconhece entre sua maneira de ver e essa filosofia a partir das próprias passagens em que ele se pronuncia a esse respeito. Como veremos, elas parecem indicar que, mesmo que não se possa afirmar que Bacon considere sua própria "doutrina dos ídolos" como "cética", é possível ir além das considerações genéricas sobre as "influências" dessa filosofia em sua reflexão e precisar o significado que ele mesmo teria conferido a tal relação. A afinidade que ele reconhece entre o diagnóstico dos saberes oferecido por tal doutrina e a posição cética parece ser de tal ordem que sua revogação dependeria, segundo Bacon, não apenas da posse do novo método de investigação da natureza que ele pretende anunciar, mas da plena efetivação do projeto de estabelecer uma Ciência acerca

Cf. POPKIN, 1979, p. 207 e p. 85, 156, 174. Popkin não oferece maiores justificativas de sua assimilação do caso de Bacon às respostas de tipo aristotélico. Na p. 208, ele afirma, contudo, que os diferentes tipos de respostas aristotélicas ao ceticismo têm em comum a visão de que há condições adequadas de funcionamento de nossas faculdades cognitivas capazes de nos propiciar conhecimento - tese esta cuja atribuição a Bacon é discutível, como veremos. Por mais que efetivamente haja aspectos da reflexão baconiana que sejam passíveis de uma aproximação estreita com o aristotelismo - ver MALHERBE, 1986, p. 36 - , uma discussão adequada dessa hipótese deve necessariamente levar em consideração as múltiplas críticas de Bacon a Aristóteles, que é por ele visto como um autor paradigmático da corrupção "racionalista" da filosofia. (Cf., por exemplo, Novum organum, § I, p. 54, 63, 67, 77.) Na edição revista da obra de Popkin, publicada em 2003, The history of skepticism from Savonarola to Bayle, não há novidades referentes a Bacon. OLIVEIRA (2002) dedica ao tema, por sua vez, um capítulo de seu livro, ao qual faremos referência adiante. 
das Formas das próprias coisas - algo que ele mesmo entende ser ainda impossível e relega ao trabalho das gerações futuras; ademais, grande parte das discussões em torno do ceticismo filosófico é freqüentemente comprometida pela vagueza do conceito de "ceticismo" com que nelas se opera - , e o caso de Bacon não parece ser exceção à regra. Assim, procuraremos igualmente considerar o modo como suas reflexões são atentas a aspectos diversos com que a reflexão cética se apresenta no ambiente intelectual do Renascimento (mesmo no que respeita à associação entre ceticismo e paradoxo literário) e à diferença entre as correntes céticas tradicionais. Todavia, no que tange a esse último ponto, pode-se constatar que a interpretação baconiana - à falta, aparentemente, de um contato mais direto com os textos de Sexto Empírico - amolda-se a suas próprias reflexões teóricas sobre o tema, de modo a convergir para uma espécie de distinção entre "ceticismo integral" e "ceticismo moderado" similar à que faria fortuna na filosofia posterior.

Notemos, antes de mais, que as referências de Bacon ao ceticismo filosófico comportam invariavelmente um elemento crítico, retomando freqüentemente os mesmos motes: os céticos são, segundo ele, aqueles que profanaram o oráculo dos sentidos e das faculdades humanas, em vez de lhes propiciar os auxílios de que necessitariam para obter a verdade, e formularam seu diagnóstico sobre nossa situação cognitiva de um modo tal que acabaram por substituir a via austera da pesquisa por um simples "passeio pelas coisas", através de dissertações agradáveis. ${ }^{1}$ Mas essas observações oferecem apenas uma imagem parcial, que nos pode conduzir a uma avaliação indevida se não levamos em conta que, em mais de uma ocasião, suas críticas se apresentam na forma de um contraponto entre a sua própria maneira de ver e aquela que seria a dos céticos. No aforismo I, $\S 37$ do Novum organum, por exemplo, Bacon escreve - acerca dos filósofos que sustentaram a suspensão do assentimento:

A reflexão (ratio) daqueles que sustentaram a acatalepsia e a nossa via, de início (initiis), em certa medida, convergem; ao final (exitu), afastam-se bastante e se opõem. Pois eles afirmam que nada se pode saber, sem mais (simpliciter); nós, que não se pode saber muito da natureza pela via que está agora em uso. Ao final, eles destroem a autoridade dos sentidos e do intelecto, e nós pesquisamos e administramo-lhes auxílios (auxilia)...2 (grifo no original).

Nesse texto, Bacon expõe a distância "final" que haveria entre sua reflexão e a dos partidários da acatalepsia (numa aparente referência aos céticos da Nova Academia, como veremos melhor), mas apenas depois de reconhecer 
uma afinidade "inicial". Um primeiro ponto importante, a nosso ver, reside em tentar compreender melhor o sentido dessa oposição entre o início (initium) e o final (exitus) dessas vias por ele comparadas. Tratar-se-ia apenas de apontar o caráter enganoso da semelhança entre essas filosofias, de modo que o "inicial" seria sinônimo de "à primeira vista"? Ou teria esse contraponto, a despeito das divergências efetivamente anunciadas, algum sentido filosoficamente mais substantivo no que tange às possíveis similaridades que Bacon veria entre a ratio dos céticos e a sua própria? Parece-nos que há razões para nos inclinarmos pela segunda opção.

Como noutras ocasiões, a distância que Bacon aí demarca relativamente aos céticos é diretamente vinculada aos auxilia que, de sua parte, ele teria pretendido administrar às nossas faculdades cognitivas. Com segurança podemos admitir que isso corresponde a uma alusão genérica ao seu próprio método indutivo, ${ }^{1}$ pelo qual ele pretendeu colaborar para o estabelecimento do que descreveu como um "genuíno casamento entre o espírito e as coisas"; um método capaz de propiciar uma efetiva interpretação da Natureza, por oposição às meras "antecipações" produzidas pela filosofia tradicional, e de alcançar, assim, o conhecimento das verdadeiras Formas, estendendo igualmente o saber e o poder do homem em uma dimensão inteiramente nova. Mas é apenas a partir do segundo livro do Novum organum (correspondente à denominada pars informans) que se inicia a exposição da parte positiva do método (através de exemplos destinados a ilustrar procedimentos práticos pelo qual a indução deveria se guiar entre as coisas particulares, sobretudo no que tange à sua disposição nas "tábuas de invenção"). E, por mais que tais ilustrações possam ser tidas como uma exposição acabada, ao menos de caráter geral, da fórmula da indução, como propõe Malherbe, a exposição plena desse método só poderia se completar na realização da filosofia, isto é, na própria Interpretação da Natureza que teria lugar posteriormente à exibição do Organum — uma vez que, por suas próprias exigências, o método se destinaria a ser capaz de uma adaptação maleável às próprias coisas, na medida do próprio avanço da pesquisa. ${ }^{2} \mathrm{O}$ Novum organum constitui, com efeito, apenas a segunda parte da Instauratio magna e, conforme ao que lemos na Distributio operis, é apenas na terceira (intitulada Phaenomena universi) que se vai além da simples preparação do caminho e se começa por nele avançar (antes de mais, através do empreendimento de uma História Natural segundo bases conceituais novas e

1 O que se poderia corroborar ainda pelo emprego da usual metáfora do percurso (via) para descrever essa relação.

2 Cf. BACON, 1986, p. 47. 
numa escala inusitada). ${ }^{1} \mathrm{Na}$ quarta parte, intitulada a Escada do entendimento (Scala intellectus), Bacon pretenderia oferecer mais exemplos dos particulares dispostos segundo as Tábuas de Invenção e, nessa medida, algo mais do que a simples esperança de progresso no conhecimento, tal como provisoriamente justificada ao final da primeira parte do Novum organum. Mas ele adverte igualmente que se trata ainda de oferecer exemplos de uma pesquisa para fins de esclarecimento. ${ }^{2}$ Nessa quarta parte, seriam apresentadas, diz ele, "por assim dizer" (tanquam), as coisas mesmas; ${ }^{3}$ apenas "por assim dizer", talvez, porque tampouco estaríamos ainda naquela que ele previu ser a etapa culminante - a Filosofia Segunda, ou Ciência Ativa, única capaz de nos assegurar o conhecimento das Formas propriamente ditas. Porém, projetada como a sexta etapa do percurso, ${ }^{4}$ essa filosofia, anteriormente preparada pela pesquisa legítima, purificada e severa, é algo que ultrapassa inteiramente suas esperanças pessoais, posto que sua realização é inconcebível, diz ele, em vista do atual estado das coisas e dos espíritos. ${ }^{5}$

Retomamos rapidamente esse percurso apenas para oferecer uma escala das dificuldades que o próprio Bacon, a despeito do seu otimismo, reconheceu se interporem ao efetivo conhecimento das coisas. Como diz ele, no prefácio da Instauratio magna, o seu próprio método é essencialmente o de uma verdadeira e legítima humilhação do espírito humano, por oposição à estimativa precipitada sobre as efetivas forças da mente:

(...) pois todos aqueles que, antes de nós, aplicaram-se à invenção das artes, lançaram um breve olhar sobre as coisas, os exemplos e as experiências, e se precipitaram a invocar seus próprios espíritos para que eles lhes oferecessem seus oráculos, como se a descoberta nada mais fosse que um jogo de pensamento... ${ }^{6}$

Chamar a atenção para esse ponto permite também observarmos melhor a continuidade metódica existente entre a pars informans do Novum organum (onde se evidencia, como dissemos, a dimensão positiva desse movimento em direção ao conhecimento das Formas) e a lenta progressão que a prepara, no Livro Primeiro, da qual fazem parte uma pars praeparans propriamente dita $\mathrm{e}$ uma pars destruens que a antecede — parte esta destinada à exposição crítica do estado atual dos saberes e a contribuir para a destruição dos impedimentos

Distributio operis, Sp. I, p. 140.

Cf. Ibidem, Sp. I, p. 143-144.

Novum organum, I, § 92, Sp. I, p. 199.

Ela seria precedida ainda pelos Pródromos, ou Antecipações da Filosofia Segunda, que corresponderiam à quinta parte da Instauratio, na qual se trataria de oferecer uma coletânea do que se pôde inventar e provar, não com o método, mas em vista do uso ordinário do entendimento. (Cf. Sp. I, p. 143-144.)

Idem.

Sp. I, p. 130. 
que bloqueiam o avanço da investigação sobre a natureza - os famosos "ídolos". Embora tais impedimentos sejam diversas vezes mencionados nas obras de Bacon, é no Novum organum que a sua exposição é mais desenvolvida e sistematizada. Denunciá-los, a seu ver, é algo indispensável para que se possam ter esperanças de evitar a repetição infinita dos erros e, por meio de uma purificação do entendimento humano, proceder a uma reconstrução radical dos saberes ab imis fundamentis. ${ }^{1}$ Ora, se o movimento inicial do próprio método baconiano exige uma recusa crítica dos saberes vigentes e se o acordo que ele entende possuir com os partidários da acatalepsia pode se exprimir em torno do lema "nada se sabe" (por mais que Bacon possa matizá-lo ao alegar que "quase nada" se sabe, que tal situação é provisória e relativa), não seria o caso de admitir que a afinidade igualmente "inicial" que haveria a sua filosofia e a dos céticos inclui uma referência ao seu próprio método (ainda que seja no que tange apenas à sua parte destrutiva)? No mesmo passo em que o aforismo acima considerado demarca a distância, não deveria ser, assim, igualmente lido como a corroboração de uma afinidade filosófica, visível tanto no sentido mais geral dos propósitos; mas também, como veremos, em alguns aspectos de maior detalhe conceitual? Isso nos oferece um primeiro indício de que Bacon reconheceria haver uma similaridade, ainda que restrita, entre o olhar cético diante do panorama dos saberes humanos e o seu próprio, tal como situado no momento inicial da investigação, isto é, no momento atual em que sua reflexão se volta na direção de um projeto futuro ainda inconcluso e cercado de dificuldades, como não cansa ele de sublinhar.

Um segundo indício assemelhado a esse diz respeito à "doutrina dos ídolos", núcleo da pars destruens, em que Bacon distingue quatro espécies de impedimentos que atuam contra nossas pretensões de obter a verdade: os "ídolos da raça" (idola tribus), decorrentes das imperfeições de nossas faculdades de conhecer - seja o intelecto, comparado a um espelho deformante que, exposto aos raios das coisas, mistura sua própria natureza à delas, falseando e embaralhando; uma faculdade refém de erros sistemáticos que ela própria é incapaz de corrigir, seja pelas suas próprias forças, seja com o auxílio da dialética; ${ }^{2}$ sejam as imperfeições dos sentidos, que, embora constituam a instância à qual se deve tudo perguntar na pesquisa da natureza, diz ele, "a menos que se queira delirar", são por si algo de fraco e enganador e não podem, quanto a isso, ser auxiliados pelos instrumentos inventados para aguçá-los e estender seu alcance. ${ }^{3}$ Em seguida, os "ídolos da caverna" (idola specus), gerados,

1 Sp. I, p. 139; Novum organum, I, § 31, Sp. I, p. 162.

2 Ver Novum organum, I, § 41, §§ 45-52. Ver também: Sp. I, p. 121, 129.

3 Sp. I, p. 138; Novum organum, I, § 50. 
segundo Bacon, pela diversidade própria da natureza de cada indivíduo, e dependentes das diferenças do corpo, da alma, da educação, do hábito, das circunstâncias fortuitas e do modo como são afetados pelos objetos. Já os "ídolos do foro" (idola fori) são aqueles particularmente residentes nas imperfeições da linguagem humana, enquanto que os "ídolos do teatro" (idola theatri) são aqueles pelos quais Bacon metaforicamente alude aos mundos imaginários inventados pelos diversos sistemas filosóficos vigentes, constituídos por noções fantasiosas e imperfeitas (dentre as quais ele enumera as de "ser", "substância", "elemento", "matéria" etc.) e por demonstrações defeituosas que são, nas suas palavras, os sistemas em potência. ${ }^{1}$

Como observou Granada, os aforismos do Novum organum que tratam explicitamente de suas relações com o ceticismo ocupam posições estratégicas relativamente à exposição dessa doutrina. ${ }^{2}$ Mais precisamente, o primeiro deles, na ordem da exposição, é o aforismo I, $\S 37$, ao qual já nos referimos, que poderia ser compreendido como um aforismo de transição entre o movimento anterior do texto, onde são abordados os comprometimentos da lógica vigente na pesquisa, bem como a dificuldade em instaurar um método adequado para investigação, e a exposição dos ídolos. Ele demarca, assim, o início da exposição dos ídolos, enquanto o próximo aforismo a tratar do assunto (I, § 67) retoma o contraponto sob um viés predominantemente crítico — os céticos são ali acusados de uma intemperança na abolição do assentimento similar à que os dogmáticos possuiriam ao aderirem às suas doutrinas, bem como de adotar um posicionamento que, mesmo quando deixam lugar para a investigação, acaba por conduzir ao seu abandono, em vista da desesperança de alcançar a verdade — dando lugar, no aforismo seguinte, a esta afirmação: "Eis o suficiente sobre as diferentes espécies de ídolos e o seu aparelho..."3. Assim, por mais que a lenta progressão do texto de Bacon pareça, à primeira vista, possuir um encadeamento pouco linear, no qual são freqüentes as antecipações e as retomadas de temas anteriormente abordados, ${ }^{4}$ esses aforismos indicam que Bacon cingiu sua exposição da doutrina dos ídolos por duas referências explícitas ao ceticismo. Ainda que ele não o afirme explicitamente,

1 Novum organum, I, § 68. Ver Novum organum, I, § 44, § 61.

2 Cf. GRANADA, p. 4.

3 I, § 68, Sp. I, p. 179.

4 Estabelecer a divisão dos momentos lógicos da progressão do texto baconiano é um problema à parte. Talvez, apesar do que se afirma no aforismo I, § 68, devêssemos incluir na exposição dos idola theatri a crítica das demonstrações defeituosas (que Bacon diz serem "as muralhas dos ídolos" e as próprias filosofias em potência), oferecida nos aforismos 69-70, como faz Malherbe (Cf. BACON, 1986, p. 15-16). Por outro lado, não é claro como a divisão entre as quatro espécies de ídolos se harmoniza com a divisão tripartite oferecida em I, $\S 115$, na qual se baseia Spedding para propor a sua divisão do texto (Cf. Sp. I, p. 165, 172). 
tais referências poderiam ser eventualmente lidas, segundo a mesma hipótese, como correspondentes a um anúncio, em primeiro lugar, da proximidade com os céticos, para posteriormente, numa abordagem mais minuciosa, aprofundar o contraponto num viés crítico, mas apenas depois de haver exposto sua própria versão da crítica do conhecimento humano, tal como formulada por essa doutrina. Se assim for, esses aforismos permitiriam mesmo precisar que Bacon focalizaria as suas afinidades com o ceticismo principalmente na formulação dessa doutrina. ${ }^{1}$

Esses dois indícios de afinidades entre Bacon e o ceticismo, extraídos da obra mais célebre de Bacon, são, por certo, um tanto conjeturais e indiretos. Contudo, seu interesse é o de nos permitirem transpor à leitura do Novum organum aquilo que ele afirma bem mais abertamente em outras passagens nas quais retoma o mesmo paralelo. Em um curto texto initulado Scala intellectus sive filum labyrinthi e composto, ao que parece, para prefaciar a parte homônima da Magna instauratio, Bacon escreve:

(...) não podemos, no entanto, absolutamente negar que, se não houvesse oposição a uma sociedade entre a nossa filosofia e as antigas, é com este gênero filosófico [i.e., o daqueles "a quem apraz o nada se sabe"] que estaríamos mais ligados; estaríamos de acordo com muitos dizeres prudentes e observações acerca das variações dos sentidos e da falta de firmeza do julgamento humano, e acerca da contenção e da suspensão do assentimento. A estas poderíamos ainda acrescentar ainda diversas outras [observações] semelhantes. A tal ponto que entre nós e eles reste apenas essa diferença: eles afirmam que nada se sabe categoricamente (prorsus) e nós afirmamos que nada se pode saber pela via que até aqui percorreu a raça humana...2 (grifos nossos).

Nesse texto, inteiramente elaborado em torno da comparação entre sua filosofia e a dos céticos, novamente surgem elementos que relativizam a aproximação. Na passagem acima, em particular, eles são projetados na forma de uma oposição mais geral entre a sua filosofia e as antigas. De fato, Bacon salienta, em vários momentos, o modo como os saberes existentes são relativos, dentre outros aspectos, ao seu local de origem, à sua época e à sociedade que os produziu e tende a condenar, de modo geral, a sabedoria dos gregos, julgando-a irremediavelmente comprometida por um viés professoral e retórico, que a impediu de avançar na pesquisa pela verdade. ${ }^{3}$ Em uma passagem do Novum organum, ele menciona o nome do cético acadêmico Carnéades entre aqueles que seriam todos, a seu ver, com maior ou menor dignidade, sofistas. ${ }^{4}$ Ainda

2 Sp. II, p. 688; devemos essa referência a Miguel Granada.

3 Ver Novum organum, I, §§ 32, 34, 61, p. 71-72.

4 Novum organum, I, § 71. 
assim, poderia ser ele mais explícito ao assinalar a existência de aspectos de sua reflexão que, no seu próprio entender, revelem um acordo com os céticos — os filósofos aos quais estaria mais ligado, apesar de sua antigüidade? Mais ainda, aqui ele nos oferece detalhes sobre os pontos em que estaria de acordo com eles, a saber, quanto aos seus "dizeres prudentes" acerca da precariedade dos sentidos e do intelecto humanos, bem como acerca da própria suspensão do assentimento. ${ }^{1}$ Por mais que esses temas sejam abordados de modo peculiar por Bacon, eles se incluem diretamente no escopo da doutrina dos ídolos: tanto dos idola tribus - referentes à precariedade das nossas faculdades cognitivas - quanto dos idola theatri - que, a seu modo, preconizam uma recusa das fantasias até então elaboradas pelas teorias filosóficas e seus métodos.

Contudo, poder-se-ia pensar que, pelo fato de Bacon apresentar seus "ídolos" com o propósito explícito de "purificar o entendimento" em vista da obtenção da verdade, essa doutrina já conteria, nesse simples passo, uma superação da perspectiva cética. Mas as coisas não são tão simples. Por mais diversos que, no seu detalhe, possam ser os ídolos baconianos dos modos suspensivos céticos e que a sua exposição tenha em vista o objetivo de contorná-los (e não o de reiterá-los indefinidamente), Bacon não cansa de sublinhar, como dissemos, a dificuldade e os limites dessa tarefa, frente ao poder de tais impedimentos. Ele qualifica dois dos gêneros de ídolos como "inatos" (a saber, os idola tribus, referentes às nossas faculdades cognitivas, e os idola specus, referentes às nossas diferenças individuais), por oposição àqueles que, embora "adventícios" (os idola fori e os idola theatri), possuem relações estreitas com os anteriores. E se os ídolos adventícios, diz ele, são muito difíceis de serem desenraizados, os inatos são descritos como impossíveis de erradicar:

(...) A única coisa que resta a fazer consiste em indicar, denunciar e confundir essa violência insidiosa do espírito, de modo a evitar que, em virtude da má compleição do espírito, a destruição dos antigos erros não gere novos, de modo que eles não sejam extirpados, mas apenas substituídos... ${ }^{2}$

Não se trata, assim, de pretender neutralizar os ídolos que bloqueiam o acesso à verdade diretamente, à maneira de uma eventual refutação do ceticismo. Mesmo que haja, segundo Bacon, procedimentos úteis para melhor

1 Assim, não nos parece adequado afirmar que Bacon faz uma "utilização não explícita" de "argumentos" filosóficos céticos. (Ver OLIVEIRA, 2002, p. 75.) Isso não significa, por outro lado, que estejamos autorizados a considerar sua doutrina dos ídolos como "cética", nem mesmo a considerá-lo como um "cético", ainda que "mitigado" ou "construtivo". Bacon faz questão de ressalvar a existência de uma "oposição a uma sociedade entre a nossa filosofia e as antigas", ressalva portadora de um alcance conceitual a ser levado em conta quando almejamos compreender como ele mesmo conciliaria suas críticas ao ceticismo e sua proximidade declarada dessa filosofia.

2 Sp. I, p. 139. 
enfrentá-los antes de avançar na via própria da experiência - como, por exemplo, a exibição dos signos (signa) do triste estado da filosofia atual, bem como as causas desse fenômeno ${ }^{1}$ — o único remédio próprio residiria, a seu ver, nos axiomas e noções que viriam a se produzir pela verdadeira indução. ${ }^{2}$ Como diz ele, metaforicamente, na Redargutio philosophiarum: embora sobre as tabuletas de fato nada se escreva novamente se não se apagaram as primeiras inscrições, no espírito haverá grande dificuldade em apagar as primeiras inscrições sem ali ter inscrito algo de novo. ${ }^{3}$ Ao invés de ser um simples resultado da superação de tais impedimentos ao conhecimento, a posse do conhecimento sobre a natureza é ela mesma, em alguma medida, condição de sua plena superação. Mas o acesso, ainda que restrito, a tais conhecimentos não implica necessariamente a plena revogação de tais impedimentos. Uma forma de compreender a situação aparentemente circular que aqui parece se criar é a de admitir que, no mesmo passo que o método opera ainda segundo uma formulação incompleta, um material experimental insuficiente ou se apoiando em conclusões provisórias, vigem ainda, em alguma medida, os mesmos impedimentos cognitivos. ${ }^{4}$ Mas, no mesmo passo, se nossa leitura estiver correta, justifica-se ainda, na mesma medida, o mesmo acordo, parcial ou provisório, com a perspectiva cética. Se à afinidade inicial que Bacon reconhece entre sua filosofia e a dos céticos corresponde uma forma de incorporação metódica do ceticismo, a despeito de haver ao final uma completa oposição, tudo se passa como se a progressão rumo ao conhecimento das coisas pudesse ser compreendida como a superação progressiva desse acordo parcial.

Se assim for, passa a ser um problema interpretativo relevante o de determinar como e em que momento dessa progressão se operaria tal superação. Por certo, as ressalvas que Bacon introduz já nas manifestações de sua afinidade com os céticos oferecem um indício claro de que cabe buscar, na formulação mesma da doutrina dos ídolos, elementos de natureza "preparatória" a

1 Novum organum, I, § 70. Tais signos e causas são efetivamente abordados posteriormente à exposição da doutrina dos ídolos, em Novum organum, I, §§ 71-77 e I, §§ 78-91.

2 Ver Novum organum, I, § 40. Em I, § 36, Bacon afirma que o único modo de transmissão do método é o de conduzir os homens aos particulares e exigir que reneguem suas noções e comecem a se familiarizar com as próprias coisas.

3 Sp. III, p. 557-558.

4 Poder-se-ia afirmar que o "método da ciência baconiana não é... o porto seguro que, como talvez em Descartes, garantiria o acesso à certeza indubitável...” (OLIVEIRA, 2002, p. 77). Mas não nos parece possível inferir, como faz ele, do reconhecimento dessas dificuldades, a conclusão de que Bacon abdicaria da pretensão de que seu método viesse a oferecer "certeza indubitável". Para Bacon, sendo objeto de conhecimento o real, embora não possamos dele ter conhecimento perfeito (universal e necessário) antes da etapa final da Instauratio, os estágios que a ela conduzem, a partir da própria História Natural, são portadores de graus definidos de certeza. (Ver, por exemplo: MALHERBE, 1996, p. 80, 85, 90, 93-94.) Essa distinção nos parece relevante se pretendemos precisar em que medida o próprio Bacon teria compreendido suas relações com o ceticismo. 
tal superação. Mas não é possível dar uma resposta precisa a esse problema sem se deter num exame detalhado do conteúdo dessa doutrina, para saber em que medida ela reproduz a problemática presente nos textos pertencentes à tradição cética ou, em vez disso, pretende nos oferecer, em suas eventuais inovações, elementos destinados a demarcar, desde o início, uma via diversa. Não adentraremos nesse terreno aqui, mas importa ressaltar que o reconhecimento do poder dos ídolos por parte de Bacon cria uma identificação com o diagnóstico cético que é normalmente subestimada, apesar do modo como ele assinala a cogência que vislumbra na posição desses filósofos. Afora o texto do Filum labyrinthi acima citado, no De augmentis scientiarum (1623), examinando as dificuldades decorrentes da ausência de princípios e métodos demonstrativos seguros para a investigação da Física, ele afirma:

(...) não foi sem grande e evidente razão que tantos filósofos, alguns deles da maior eminência, tornaram-se Céticos e Acadêmicos (Sceptici et Academici) e negaram qualquer certeza de conhecimento ou apreensão (scientiae humanae et syllepsium), afirmando que o conhecimento do homem se estende apenas a aparências e probabilidades... ${ }^{1}$

Poder-se-ia alegar, contra a hipótese de leitura aqui formulada, que são inconclusivos os indícios de que a doutrina dos ídolos teria se constituído a partir de fontes céticas. Mas que alternativas nos restam quando se pretende reconhecer aquelas que seriam aqui filosoficamente relevantes? Por vezes, tentou-se aproximar essa doutrina dos quatro "impedimentos à verdade" (offendicula veritatis) enumerados por Roger Bacon no início do seu Opus majus - o uso de uma "autoridade insuficiente", o costume, a opinião popular e o disfarce da ignorância acompanhado pela presunção de conhecimento mas Spedding argumenta persuasivamente para mostrar que tal parentesco é artificial e improvável. ${ }^{2}$ Mais recentemente, Deleule objetou às tentativas de aproximar a doutrina baconiana ao ceticismo, preferindo remeter a noção de idolum ao platonismo e ao epicurismo, fontes a que Bacon teria explicitamente feito menção - ao se referir, por exemplo, à crítica de Cotta ao antropomorfismo epicurista no De natura deorum, de Cícero. ${ }^{3}$ Mas importa lembrar que, nesse diálogo, Cotta é o personagem designado para representar a Nova Academia, pela qual o próprio autor exprime sua simpatia pessoal. ${ }^{4}$ Tampouco a

Cf. Sp. I, p. 163. Segundo Spedding (Ibidem), não apenas o princípio de classificação é diverso, como os problemas enumerados por Roger Bacon são muito mais restritos que os apontados por Francis Bacon (de modo que poderiam, na melhor das hipóteses, ser subordinados aos idola fori e aos idola theatri). Ademais, diz ele, é improvável que Francis Bacon tenha lido seu homônimo, dada a inexistência de edições impressas dessa obra e de indícios de um interesse específico de sua parte por esse autor.

BACON, 1987, p. 36.

Ver CICERO, 1994, p. 11-14. 
hipótese de Deleule se fortalece pelo fato de a noção de idolum, como alega ele, ser recorrentemente associada por Bacon ao vocabulário da imaginação e da fantasia - tal como ocorre, por exemplo, na sua abordagem dos "ídolos do teatro", resultantes do modo como o entendimento humano se deixa naturalmente conduzir pela imaginação. ${ }^{1}$ Tal tema, mesmo que Bacon o aborde de forma peculiar, é recorrente na literatura cética. Já Sexto Empírico se refere à teoria da alma proposta por Platão como "imaginária", valendo-se de um termo - eidolopoiesis - etimologicamente afinado ao que Bacon escolheu em sua crítica. ${ }^{2} \mathrm{O}$ mesmo tema se amplifica e ganha um desenvolvimento próprio em obras contemporâneas de Bacon que evidenciam elementos céticos, como o Quod nihil scitur, de Sanchez e os Ensaios de Montaigne. Na Apologia de Raimond Sebond, além de qualificar os conceitos fabricados pela filosofia natural como "sonhos e fantásticas loucuras", ${ }^{3}$ Montaigne caracteriza a própria razão e o entendimento humano como fontes de ficções. ${ }^{4}$

Pela mesma razão, parece-nos que Platão não poderia ser assumido como fonte dessa doutrina - a não ser pelo viés da ironia ou de uma leitura ceticizante. É bem verdade que Bacon se refere explicitamente, no The advancement of learning (1605), à Alegoria da Caverna para ilustrar como as compleições e costumes individuais geram infinitos erros e falsas opiniões, oferecendo, assim, um esboço daquilo que corresponderia futuramente aos idola specus. Mas já ali ele mesmo cuida de assinalar, em uma nota marginal, que não teve a intenção de imprimir a essas considerações o sentido que o próprio Platão teria conferido à metáfora. ${ }^{5}$ Por outro lado, embora reconheça, no Novum

1 Cf. Novum organum, I, § 44, § 15, § 47.

2 Ver SEXTUS EMPIRICUS, 1993, livro I, p. 189. Doravante, todas as citações a essa obra serão referidas pela sigla $H P$, seguida pelo algarismo que indica o livro de onde provém e pelo número da página. Assim Sexto comenta, por exemplo, a teoria pitagórica dos números: "Tais são as ficções que eles imaginam..." (HP, III, p. 156). Em HP, III, p. 114, concluindo sua investigação crítica sobre as noções de geração e corrupção proposta pelos filósofos dogmáticos, ele afirma que sua física é "irreal e inconcebível". O mesmo termo grego é igualmente utilizado por Sexto no contexto de uma crítica mais genérica dos dogmatismos. (Ver, por exemplo: HP, II, p. 222.)

3 MONTAIGNE, 1999, 12, p. 536 [AC]: "Que algum dia apraza à Natureza abrir-nos seu seio e nos faça ver propriamente os meios e as condutas dos seus movimentos, e a isso prepare nossos olhos! Ó Deus! quais abusos, quais imposturas nós não encontraríamos em nossa pobre ciência: eu me engano se houver uma única coisa que ela mantenha corretamente no devido ponto...”. Também Sanchez qualifica as explicações filosóficas tradicionais como ficções. Por exemplo, empregando um argumento aristotélico contra a tese platônica segundo a qual haveria uma identificação entre conhecer e lembrar, ele afirma: "(...) Com minhas desculpas a esse pensador normalmente tão brilhante, esta é uma ficção desprovida de fundamento (leue admodum figmentum), que não se sustenta nem pela experiência nem por argumento racional - como mil outros sonhos que ele sonhou acerca da alma, como irei demonstrar no meu 'Tratado sobre a Alma'..." (SANCHEZ, 1988, p. 17).

4 “(...) Eu chamo razão nossos devaneios e sonhos, com a autorização da filosofia, que afirma que mesmo o louco e o raivoso enlouquecem pela razão, mas que se trata de uma razão de forma particular..." (II, p. 12, 523 [A]). Ver também: II, p. 12, 516, 562.

5 Cf. Sp. I, 396. Segundo Spedding, Bacon acrescenta à alegoria, entre parênteses: "missa illa exquisita parabolae subtilitate" (pondo-se à parte a tão refinada sutileza da parábola). 
organum, que a escola desse filósofo tenha sido a responsável pela introdução da acatalepsia, ele o considera como paradigmático do gênero "supersticioso" de filosofia. ${ }^{1}$ Finalmente, na mesma linha de considerações, mesmo que Bacon oponha os ídolos produzidos pela mente humana às idéias que se encontram exclusivamente no conhecimento divino, ${ }^{2}$ cabe lembrar que ele nunca emprega o termo idolum no sentido corriqueiro de "falsos deuses", ${ }^{3}$ para não mencionar sua insistência em separar os terrenos da ciência natural e o da teologia. ${ }^{4}$ Se convém, afinal, nos atermos às indicações dadas pelo próprio autor, não seriam os elementos acima mencionados mais seguros e filosoficamente mais relevantes ao apontar afinidades entre a doutrina dos ídolos e o ceticismo?

Todavia, há outros problemas em aberto dos quais essas especulações parecem depender, talvez decisivos para o prosseguimento deste exame: Quais são as fontes céticas de que efetivamente se serviu Bacon? Como ele as interpretou? Sem pretender esgotar esse tema, esboçaremos aqui algumas considerações que talvez sejam úteis para uma abordagem posterior mais aprofundada.

Primeiramente, embora o problema de determinar as fontes precisas do texto de Bacon seja particularmente delicado (dentre outros motivos porque, em conformidade aos códigos literários do período, ele raramente as menciona), um texto que já citamos revela que Bacon é atento, em alguma medida, à diversidade das fontes céticas, diferenciando sceptici de academici. Ademais, ainda que ele tenda, de modo geral, a tratar essas duas vertentes em bloco, segundo o viés conceitual de sua própria crítica, há textos em que ele leva em conta diferenças que discerne entre essas escolas. No aforismo 67 do Novum organum, depois de brevemente historiar a posição dos que professaram a acatalepsia, introduzida por Platão contra os sofistas e transformada num dogma pela Nova Academia, ele escreve:

Esse procedimento é certamente mais honesto do que aquele dos pronunciamentos arbitrários, posto que tais filósofos declaram, em sua defesa, que não obstam de modo

1 Ver, respectivamente: I, § 67; I, § 65.

2 Novum Organum, I, § 23, Sp. 160.

3 Como igualmente assinalou Spedding (Cf. Sp. I, p. 89). Há contudo três exceções notadas por LE DOEUFF (1985, p. 43), cuja autoridade baconiana, como essa comentadora mesmo reconhece, é duvidosa.

4 Ver, por exemplo: Sp. 132, I, §§ 65, 68. Le Doeuff pretende identificar um sentido teológico oculto na doutrina dos ídolos. (Cf. Op. cit., p. 43.) Parece-nos, contudo, que sua interpretação, ao pretender conferir a certas noções baconianas (como a noção de esperança) um estatuto "epistemo-teologal" (p. 38, 42), peca pelo recurso a um conceito exterior à própria reflexão baconiana que parece conflitar com a distinção entre ciência e teologia que ele pretende respeitar. (Idem, Ibidem.) Isso não significa que não se possa reconhecer aspectos da reflexão filosófica de Bacon como inteiramente harmônicos com temas teológicos por ele mesmo invocados, desde que cuidemos de não confundir esses dois domínios que Bacon mantém separados. 
algum a investigação, como fizeram Pirro e os Céticos (Ephetici), mas que sustentam como dignas de aprovação (probabile) as opiniões que adotam, sem contudo aceitá-las como verdadeiras...

Bacon criticará igualmente, em seguida, esses filósofos que não teriam pretendido abandonar a investigação, pois, diz ele, uma vez que o espírito humano perde a esperança de encontrar a verdade, o interesse pela investigação se enfraquece e ela degenera em meras disputas e dissertações agradáveis. ${ }^{2}$ Mas quem seriam esses filósofos (que não obstam a investigação), segundo Bacon? Mesmo que talvez o texto admita alguma ambigüidade, o contexto aponta, não para os céticos pirrônicos, mas para os partidários da Nova Academia, isto é, aqueles que, além de não obstarem a investigação, aceitam as opiniões como probabile - o critério prático segundo a tradicional formulação desses filósofos, tal como a encontramos, por exemplo, em Cícero. Esse detalhe interpretativo pode ser útil para avaliarmos o contato de Bacon com as fontes céticas tradicionais. De fato, nos Academica, Cícero advoga a posição desses filósofos sustentando que a certeza não é indispensável para a ação segundo a vida comum e para o engajamento nas artes, referindo-se mesmo ao prazer que os céticos acadêmicos encontrariam na investigação de temas de suprema magnitude e grande obscuridade, bem como no encontro de uma noção que apenas pareça ter uma semelhança com a verdade. ${ }^{3}$ Mas teria Bacon proposto esse contraponto, no que tange à relação entre suspensão do juízo e interesse pela investigação, levando em conta o modo como Sexto se refere, no início das Hipotiposes, aos céticos pirrônicos como aqueles que "permanecem investigando", por oposição, precisamente, aos partidários da Nova Academia, que teriam sustentado a impossibilidade de conhecimento como uma espécie de dogmatismo negativo $?^{4} \mathrm{E}$ ainda que as críticas de Bacon tenham em vista a concepção particular de investigação dos pirrônicos tal como proposta por Sexto (concebida como uma atividade de neutralização da precipitação dogmática, essencialmente negativa), os termos com que ele usualmente alude ao modo como o ceticismo acabaria por comprometer a investigação (transformando-a em dissertações agradáveis ou "passeios pelas coisas") parecem evocar, não os textos de Sexto, mas antes o próprio Cícero ou, eventualmente,

1 Novum Organum, I, § 67, Sp. I, p. 178. No original: “(...) Quae [Acatalepsiam tenere] licet honestior ratio sit quam pronunciandi licentia, quum ipsi pro se dicant se minime confundere inquisionem, ut Pyrrho fecit et Ephetici, sed habere quod sequantur ut probabile, licet non habeant quod teneant ut verum...".

2 Nos termos do Filum labyrinthi, a mesma desesperança acaba por cortar "os nervos da inquisição humana". Ver Sp. II, p. 687.

3 Ver Academica, II, p. 108, 127-128.

4 Ver HP, I, p. 1-4, 7. 
Montaigne. ${ }^{1}$ Ademais, se levamos em conta as considerações de Sexto sobre as afinidades entre o pirronismo e a Medicina Metódica dos gregos, sobre o assentimento prático ao phainómenon e, muito particularmente, sobre o modo como este seria compatível com a prática das tékhnai, voltadas à busca do que é útil ao bem estar humano, como estudos recentes têm enfatizado, ${ }^{2}$ seria plausível admitir que Bacon reconhecesse uma afinidade ainda maior entre sua própria perspectiva e a dos céticos. Isso parece indicar, ao menos, que é pouco provável que Bacon tenha lido Sexto Empírico (ou, pelo menos, as Hipotiposes) — ainda que Spedding tenha apontado o Adversus logicus, do mesmo autor, como fonte de uma alusão de Bacon a Heráclito na apresentação dos idola specus. ${ }^{3}$

Já no De augmentis scientiarum, depois de alegar que muitos dos grandes filósofos tiveram razão em se tornar céticos e acadêmicos, seguindo apenas as aparências e probabilidades, Bacon opina que tanto Sócrates quanto Cícero não teriam "sinceramente" (sincere) sustentado a incapacidade da mente em obter a verdade (mas apenas em vista propósitos irônicos e retóricos) e afirma: "É certo, contudo, que houve alguns, aqui e ali, tanto na Nova quanto na Antiga Academia, e muito mais entre os Céticos, que sustentaram essa opinião em sua simplicidade e integridade (simpliciter et integre)." "4. Assim, além de diferenciar essas correntes filosóficas, Bacon parece levar em consideração duas modalidades distintas de adoção de uma postura cética: uma modalidade mais radical, que teria admitido a impossibilidade de reconhecer a verdade de forma integral e simples (principalmente associada ao pirronismo, mas talvez com aderentes também entre os acadêmicos), e uma modalidade mais branda, exemplificada por Sócrates e Cícero, segundo a qual se poderia admitir uma

1 Ver, especialmente, Ensaios, I, 50, p. 301-302: "[A] O julgamento é uma ferramenta para todos os fins, e se mete em toda parte. Por essa causa, nos ensaios que dele faço aqui, emprego todo tipo de ocasião. Se for um assunto que eu não entendo, por isso mesmo eu o ensaio, sondando de longe o leito; se o acho demasiado fundo para meu tamanho, fico na margem. E esse reconhecimento de não poder atravessar é um traço de seu efeito, e mesmo daqueles do qual ele mais se orgulha. Por vezes, num assunto vão e desimportante, eu ensaio ver se ele achará de que lhe dar corpo, e de que lhe apoiar e sustentar. Por vezes, levo-o a passear por um assunto nobre e já muito trabalhado, no qual ele nada tem a encontrar por si, estando já o caminho tão desbravado que ele não pode senão marchar sobre os passos de outrem. Lá ele faz sua tarefa ao escolher a estrada que lhe parece a melhor e, de mil trilhas, ele diz que esta ou que aquela foi mais bem escolhida. Eu tomo ao acaso o primeiro tema. Eles me são igualmente bons. $E$ não pretendo nunca pô-los em evidência por inteiro... Semeando aqui um dizer, ali outro, fragmentos desprendidos do seu lugar, afastados, sem desígnio e sem promessa, eu não me comprometi em fazer melhor, nem de neles me apoiar eu mesmo, sem variar quando assim me aprouver; assim [posso eu] entregar-me à dúvida e à incerteza, à minha forma mestra ('forme maitresse'), que é a ignorância...".

2 Além dos estudos pioneiros de FREDE (1987), no Brasil, BOLZANI (1991), SMITH (1995) e PORCHAT (2005) têm salientado diversos pontos de aproximação entre o pirronismo de Sexto e aspectos do empirismo filosófico moderno. Ver, especialmente, PORCHAT, p. 19. Cf. Hipotiposes pirronianas, I, p. 237.

3 Ver Sp. I, p. 164; Cf . Novum organum, I, § 42, Adversus dogmaticos I, p. 133; II, p. 186.

4 Sp. I, p. 621-622; IV, p. 412. 
adesão à suspensão subordinada a fins diversos, ou uma recusa não-integral da possibilidade de reconhecer a verdade. Se cotejamos essa passagem com o texto do aforismo I, $\S 67$, do Novum organum anteriormente citado, ela parece sugerir, afinal, que Bacon tenderia a ver uma maior proximidade entre sua própria maneira de ver e a posição de alguns desses filósofos majoritariamente associados à Nova Academia, na medida em que neles projeta, mesmo sem se valer dessa expressão, uma espécie de ceticismo mitigado (e mais próximo, nessa medida, de facultar o desenvolvimento de uma investigação acerca da verdade). Esse texto, ademais, parece fortalecer a sugestão de que Bacon tenha tido algum contato com as obras céticas de Cícero (autor que, segundo ele, faz parte daqueles que abraçaram a Nova Academia, mas sobretudo em vista do propósito de dissertar eloqüentemente in utramque partem, de ambos os lados da mesma questão). ${ }^{1}$ E mesmo, em vista do conteúdo de sua interpretação, com a apresentação do ceticismo oferecida por Diógenes Laércio em Vidas dos filósofos ilustres, como igualmente sugeriu Emil Wolff. ${ }^{2}$

Ainda assim, é notável a maneira como alguns aspectos da exposição da doutrina dos ídolos parecem evocar o ceticismo exposto por Sexto - especialmente, ao que nos parece, no que tange aos idola specus que, como vimos, são referentes às diferenças dos indivíduos quanto ao corpo, à alma, à educação, ao hábito e às circunstâncias como são afetados pelos objetos. O Segundo Tropo de Enesidemo alega, precisamente, que as diferenças entre os homens, seja no que tange à sua constituição corporal (em que se incluem também a diversidade de preferências e da maneira como são afetados pelos órgãos dos sentidos), ou no que tange à presumível diferença no que respeita à alma (a julgar pela diversidade irredutível das suas opiniões), devem nos conduzir à suspensão do juízo ante a ausência de critérios pelos quais possamos elidir tal controvérsia. ${ }^{3}$ Ressalvadas as diferenças que se poderiam apontar entre tais textos - por exemplo, no que tange à modalidade das oposições estabelecidas ou, como assinalou Moody Prior, à ausência dos argumentos próprios presentes no tropo pirrônico ${ }^{4}$ - há diversos outros temas, nesse e em outros momentos da doutrina dos ídolos, que se prestariam a uma aproximação conceitual com o que observamos nos textos de Sexto: por exemplo, a recusa baconiana das antecipações do espírito que marcam a filosofia tradicional

1 Cf. Sp. I, p. 621-622; IV, p. 412; segundo Emil Wolff, embora Bacon distinga entre pirrônicos e acadêmicos, ele sempre se apóia em Cícero e Diógenes Laércio apud GRANADA. Como vimos, ele parece aludir ao De natura deorum como uma das fontes da noção de idolum.

2 Cf. nota anterior. Granada igualmente parece se inclinar na direção da mesma avaliação quanto às fontes que Bacon leva em consideração.

3 Novum organum, I, § 41, §§ 53-58; HP, I, p. 80.

4 Ver PRIOR, 1968, p. 141. Todavia, parece-nos excessivo afirmar, como faz esse comentador, que se encontrariam na doutrina dos ídolos todos os "modos céticos", ainda que incorporados numa nova análise. 
(assemelhada à crítica pirrônica da propéteia, a precipitação dogmática), ${ }^{1} \mathrm{o}$ modo como a "novidade" ou o costume podem ser fatores de distorção cognitiva (como Sexto assinala no Nono Tropo de Enesidemo, baseado na raridade e na freqüência com que as coisas se apresentam), ${ }^{2}$ ou mesmo a crítica às imprecisões e erros dos sentidos (que parecem remeter aos temas dos Tropos Terceiro, baseado nas percepções conflitantes segundo os diversos sentidos humanos, ou Quinto, baseado na oposição segundo a diversidade das posições e situações de percepção). ${ }^{3}$

Uma possibilidade a ser considerada é a de que Bacon tenha tido acesso a esses materiais através de outras fontes. Segundo Granada, na crítica dos ídolos, tanto no que tange aos sentidos quanto ao intelecto em seu funcionamento espontâneo, seria possível reconhecer uma "coincidência" com a crítica cética, tanto em sua versão grega quanto em sua versão renascentista. ${ }^{4} \mathrm{E}$ o fato de os tropos de Enesidemo serem também expostos em Diógenes Laércio, ainda que de modo pouco detalhado, sugere que sua presença não remeta necessariamente a Sexto. Mas mesmo que as menções explícitas de Bacon aos céticos e acadêmicos pareçam apontar principalmente aos antigos, como vimos, talvez devamos conferir um peso maior às eventuais fontes contemporâneas que ele reconheceu como afeitas ao ceticismo. É importante, ademais, levarmos aqui em consideração o modo como Bacon reconhece a presença de elementos céticos mesmo em autores que, a seu ver, não teriam sustentado a suspensão do assentimento "sinceramente", pois isso nos adverte que ele os pode ter admitido na elaboração da sua doutrina dos ídolos mesmo sem estar disposto, eventualmente, a reconhecer tais fontes como "integralmente" céticas.

De todo modo, Bacon também alude a autores contemporâneos que relaciona ao ceticismo. Tais alusões, mesmo quando possuem um viés crítico, revelam sua atenção para as peculiaridades com que tal filosofia então se apresentava. No opúsculo Temporis partus masculus, ele se refere a Agrippa de Nettesheim, autor do De incertitudine et vanitate scientiarum et artium (1531), como uma espécie de "bufão de rua" (trivialis scurra) que tudo distorce e leva ao riso, descrevendo, na mesma obra, o ceticismo como uma filosofia que "o anima e o conduz a rir", pelo modo como leva os filósofos a "girarem em círculos". Talvez seja possível, como propôs Granada, que

1 Novum organum, I, § 9, v. 1, §§ 19-30, § 56; Cf. HP, I, p. 20, 177, 186; II, p. 17, 21, 37; III, p. 280.

2 Novum organum, I, § 56, § 119; Cf. HP, I, p. 141.

3 Novum organum, I, § 50; Cf. HP, I, p. 91, 118.

4 Cf. GRANADA. Por sua vez, OLIVEIRA (2002, p. 77) opina que Bacon seria um "elo fundamental de ligação entre o tipo de perspectiva cética desenvolvida uma geração antes por Montaigne e Sanchez e que será depois adotado por membros fundadores da Royal Society".

5 Ver Sp. III, p. 536. 
essa avaliação se justifique por uma rejeição de Bacon ao fideísmo antiintelectualista desse autor. Alternativamente, talvez devamos levar em conta que o ceticismo, ao longo do século XVI, é freqüentemente objeto de uma associação literária com a retórica do paradoxo e da ironia, tal como ocorre no Elogio da loucura, de Erasmo, na obra de Rabelais e na própria Vanitate scientiarum de Agrippa. ${ }^{1}$ Bacon, como vimos, reconhece que tal associação é possível em autores que sustentam posições dubitativas, como no caso de Sócrates, e, na mesma passagem do Temporis partus masculus, afirma que ali ele próprio se põe a escrever sob o véu da invectiva (maledictus), o que lhe permite expor sua crítica de forma concisa, escolhendo as expressões com que alveja particularmente cada um dos autores criticados. ${ }^{2}$ Não poderia a própria crítica de Bacon a Agrippa ser, em alguma medida, um produto do mesmo expediente retórico irônico? Isso se acomodaria bem com a hipótese proposta por Deleule, segundo a qual esse opúsculo, tal como outros que são produzidos anteriormente ao Novum organum, constituiriam experiências retóricas destinadas à persuasão dos diversos leitores a quem se dirige em busca de viabilizar a tarefa coletiva da Instauratio. ${ }^{3}$ Nesse caso, a crítica de Bacon ao ceticismo aí presente seria apenas o resultado paradoxal de uma estratégia literária cética associada à tradição do paradoxo. E a primeira impressão de crítica aos céticos (pelo modo como sua própria investigação os conduziria a uma pesquisa errante) poderia dar lugar a outra leitura, aparentemente mais fiel à literalidade do texto, segundo a qual o ceticismo, em vez disso, diverte-o ao exibir a precariedade das filosofias que pretenderam afirmar à verdade (assinalando, talvez, o modo como se enredariam em "círculos" demonstrativos). Não seria essa leitura mais conforme aos elogios que Bacon dirige aos céticos nos textos aqui considerados? Num caso ou noutro, a passagem testemunharia que Bacon foi atento a diferentes facetas do ceticismo contemporâneo.

Mas Agrippa não constituiria a referência mais relevante para as afinidades céticas admitidas por Bacon. Formigari e, posteriormente, Granada apontaram, de modo bastante persuasivo, diversos aspectos em que as críticas do Quod nihil scitur (1581), de Francisco Sanchez, se aproximam de aspectos da doutrina dos ídolos - seja no que se refere às críticas à noção aristotélica de ciência compreendida como conhecimento perfeito a partir das causas, a crítica à linguagem ou ao reconhecimento dos obstáculos ao conhecimento derivados da organização social dos saberes e da brevidade da vida. ${ }^{4}$ Além disso,

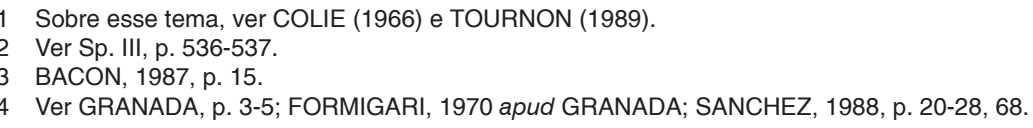


Sanchez, como Bacon, nos idola tribus, se detém em expor os erros e imperfeições do intelecto e dos sentidos humanos, incapazes de nos oferecerem acesso ao que seriam as coisas em si mesmas. ${ }^{1}$ Bacon, igualmente, a despeito de propor um método que nos capacitaria a ter acesso às formas próprias das coisas, reconhece haver uma dimensão "interna" das operações da própria natureza que, para além do que se oferece a nós pela conjunção ou disjunção dos corpos naturais, por força das limitações de nossas faculdades, nos escapa necessariamente. ${ }^{2}$ Ademais, embora Sanchez não admita ser possível dispormos de "conhecimento perfeito", admite que a experiência pode nos oferecer uma forma imperfeita de conhecimento das coisas, capaz de diferir em escopo, clareza e graus, e anuncia uma obra destinada a elaboração de um método voltado a esse fim. ${ }^{3}$ Desse modo, por mais que tenham perspectivas diversas relativamente ao potencial alcance de nosso conhecimento, ambos os filósofos valorizaram a experiência sensível como fonte privilegiada de conhecimento, sem com isso pretender que nossas percepções ofereçam imediatamente alguma espécie de certeza. Se Sanchez elabora suas reflexões sobretudo a partir de fontes acadêmicas, e aparentemente não conheceu os textos de Sexto, ele aparece como um forte candidato a representar a versão do ceticismo que teria sido mais simpática a Bacon em vista de suas próprias posições. ${ }^{4}$

Por essa mesma razão, contudo, o Quod nihil scitur parece ser uma fonte insuficiente para a explicação da presença dos elementos pirrônicos que, como dissemos, difusamente apareceriam na doutrina baconiana, caso esteja correta a hipótese de que ele não teve acesso direto às Hipotiposes de Sexto. Esta seria uma razão a mais para levarmos igualmente em consideração os Ensaios (1580-1588) de Montaigne - nos quais, como bem assinalou Popkin, fazem-se presentes praticamente todos os itens do arsenal argumentativo do pirronismo segundo a apresentação de Sexto. ${ }^{5}$ Num estudo notável, embora pouco mencionado pelos especialistas, Pierre Villey nos mostra que Bacon efetivamente leu e se reportou aos Ensaios - traduzidos ao inglês e publicados, em 1603, por John Florio - em momentos diversos de sua trajetória

2 Novum organum, I, § 4, Sp. I, p. 157.

3 SANCHEZ, 1999, p. 55.

4 Há intérpretes que entendem o contrário, embora tendamos de nossa parte a concordar com POPKIN, 2000, p. 84-85. Este autor se refere, ademais, a interpretações que, em vez de considerar Sanchez como cético, veriam-no como a um "empirista abrindo novos caminhos e preparando o terreno para Francis Bacon", que apenas teria se valido de argumentos céticos contra o aristotelismo reinante. Contudo, embora haja razões para discordar dessa avaliação, como faz o próprio Popkin, talvez permaneça havendo boas razões para aproximar Sanchez de Bacon em vista de uma reavaliação da própria natureza da doutrina dos ídolos. 
intelectual. ${ }^{1}$ Segundo Villey, buscou-se equivocadamente a principal influência de Montaigne sobre Bacon nos Ensaios deste autor, cujo parentesco com a obra de Montaigne é remoto, ainda que o título da obra baconiana seguramente tenha sido, segundo esse comentador, nela inspirado. As afinidades filosóficas, diz Villey, se manifestariam de modo mais claro na obra madura, particularmente na relação entre as críticas ao conhecimento humano, tal como expostas na doutrina dos ídolos, e as argumentações de cunho cético da Apologia, como atestam as numerosas e detalhadas aproximações textuais que ele mesmo se detém em enumerar (nas quais se incluem textos sugerindo que Bacon teria de fato interpretado Montaigne como um filósofo cético, tal como usualmente se fez no período). ${ }^{2}$ Villey tem o cuidado de manter suas aproximações num regime hipotético, frente à ausência de evidências conclusivas. Todavia, os indícios disponíveis o levam a concluir, não apenas que seguramente Bacon leu Montaigne, mas que tal leitura teria despertado e aguçado seu espírito crítico para a apreciação da fraqueza dos métodos filosóficos disponíveis e da razão humana abandonada a suas forças. A tal ponto que se justificaria melhor uma aproximação entre esses dois autores do que aquela que mais comumente se faz entre Montaigne, Descartes e Pascal. ${ }^{3}$

Em suma, é possível que Bacon tenha constituído um elo importante na própria constituição da noção de um ceticismo "mitigado", ${ }^{4}$ bem como na construção moderna da imagem historicamente discutível do ceticismo pirrônico como uma filosofia cuja radicalidade dubitativa a oporia inapelavelmente aos ideais modernos de investigação da natureza. Ainda que pouco estudado, proporcionalmente à relevância de sua obra, Bacon foi lido com interesse por filósofos que serão fundamentais na maneira como tal imagem se divulgará

1 VILLEY, 1973, p. 10-14. Para além do fato de que o diplomata Antony Bacon, irmão do filósofo, morou doze anos na França e se correspondeu com Montaigne, Villey elenca como indícios do contato de Francis Bacon com essa obra o título dos próprios Ensaios de Bacon, uma alusão explícita a Montaigne no De augmentis scientiarum, bem como um exemplo de explicação psicológica cuja fonte seguramente são os Ensaios. Contudo, pondera Villey, a influência da obra pode ser bem mais considerável do que aparenta, seja pelos códigos de citação do período, seja pela maneira pouco sistemática pela qual os Ensaios de Montaigne exibem suas reflexões.

2 Ibidem, p. 77, 100. A passagem de Bacon a que Villey se refere encontra-se em De augmentis, V, II, a qual ele aproxima das aproximações entre homens e animais que se encontram na primeira parte da Apologia. O próprio Villey, contudo, julga abusivo considerar Montaigne um filósofo cético (p. 105). Para uma interpretação diversa tomo a liberdade de remeter a meu livro que se encontra no prelo (Cf. Referências bibliográficas).

3 Ibidem, p. 109. Também aqui as aproximações entre Bacon, Montaigne e Sanchez podem talvez ser ainda estreitadas, para além dos pontos já mencionados, seja no que tange à separação entre a investigação da natureza e as questões religiosas, ou no que tange a aspectos positivos como a valorização da experiência que igualmente se depreende do texto montaigneano, como também assinala OLIVEIRA, 2002, p. 78. Menos claras e precisas nos parecem as considerações desse comentador sobre as relações entre esses autores no que tange aos "limites do conhecimento" e à passagem dos "fenômenos à natureza" (Ibidem).

4 No mesmo sentido, ver OLIVEIRA, 2002, p. 75. 
pela posteridade, como é o caso de Hume. Por outro lado, vimos que isso não significa que ele não tenha absorvido em suas reflexões próprias, ainda que os adaptando e transformando, elementos provenientes do ceticismo, mesmo em sua versão pirrônica, numa dimensão filosoficamente mais expressiva do que se pode verificar em outros autores modernos mais comumente associados à repercussão dessa filosofia. Por mais distintas que sejam as filosofias de Descartes e Bacon, é lícito dizer que, tanto na Primeira Meditação cartesiana, quanto na doutrina dos ídolos baconiana, estamos diante de reconstruções metódicas que não apenas se inspiram da dúvida cética, mas pretendem refletir, em alguma medida, o reconhecimento da cogência e da atualidade do diagnóstico cético da falta de fundamentos do conhecimento. Sem se pretenderem elas próprias céticas, almejariam ser capazes de abarcar a profundidade dessa mesma problemática, tal como exposta por tais filósofos, que pretendem superar. Igualmente, a particularidade das estratégias próprias com que cada um deles visa tal fim deixar-se-ia entrever já no nível da reformulação de tais problemas, nas partes "destrutiva" ou "dubitativa" de suas reflexões, que, cada qual a seu modo, preparariam o terreno para o advento de uma nova filosofia.

Mas aqui cabe salientar a distância que separa Descartes e Bacon. No caso de Descartes, ainda que a dúvida metódica perdure até o final da Sexta Meditação, o processo de sua superação inicia-se no início da Segunda, na qual já se pode admitir a certeza arquimediana do cogito, que conduzirá a reconhecer nas idéias claras e distintas um critério de verdade. A rigor, por mais que a dúvida importe na estruturação da Metafísica, sua plena vigência restringe-se apenas à Primeira Meditação, e na Sexta, findo o percurso, ela poderá aparecer, segundo o próprio autor, como "hiperbólica e ridícula". ${ }^{1}$ Enquanto Descartes se apresenta ele mesmo como o filósofo capaz de conquistar uma certeza para além da dúvida mais radical que os céticos pudessem propor, Bacon não pretende avançar, de sua parte, nenhuma teoria completa ou universal, nem mesmo entende que isso seja possível, como vimos, em vista do atual estado das coisas e dos espíritos. ${ }^{2}$ Ele se limita a apontar àquela que seria a via adequada para a superação desse estado de indigência dos saberes humanos, oferecendo indícios relevantes de uma nova indução, capaz de conduzir os homens progressivamente à completa reinvenção de princípios e

1 Procuramos sustentar, no nosso artigo, EVA (2001), que Descartes não teria pretendido ele mesmo que os argumentos pelos quais institui a dúvida hiperbólica fossem possuidores de uma validade autônoma; eles teriam, em vez disso, sua validade inteiramente subordinada às decisões metodológicas tomadas ao início das Meditações, que visando obter "algo de firme e constante nas ciências", distorcem deliberadamente os parâmetros cognitivos vigentes na nossa atitude natural (ao identificarem, por exemplo, o falso e o duvidoso). Eis porque Descartes a apresentaria expressamente como uma dúvida "fingida", "hiperbólica e ridícula".

2 Ver Novum organum, I, § 116. 
axiomas. ${ }^{1}$ A empresa que ele pretende anunciar não é tarefa de um homem só, e nela pouco espaço há para os talentos individuais, cujo poder de persuasão não deve se confundir, diz ele, com a verdadeira pesquisa da natureza. ${ }^{2}$ Tal empresa coletiva, porém, permanece inútil se não for possível contornar os erros radicais que intervêm, segundo ele, já na primeira digestão do material da experiência - se não for possível, noutros termos, contornar progressivamente os ídolos cuja vigência permanece dando razão aos céticos quando suspendem o juízo diante dos saberes que se pretendem disponíveis. ${ }^{3}$

Assim, mesmo que as causas de nossa incapacidade de conhecer, por Bacon identificadas em sua doutrina dos ídolos, possam divergir das apontadas pelos céticos, ele pretendeu acolher, em sua própria filosofia, a relevância filosófica própria do ceticismo mais generosamente do que ocorreu no caso de Descartes. O "ceticismo temporário" que cumpriria adotar por meio dessa doutrina, embora corresponda, na formulação precisa que adquire em Bacon, a uma parte do método, não se resume, para ele, ao fruto de uma decisão metodológica que poderia ser revogado juntamente com essa própria decisão, mas é o reflexo da avaliação de nossos limites cognitivos efetivamente vigentes. Assim, por mais que a posteridade tenha normalmente se voltado para a dúvida metódica cartesiana quando buscou uma versão moderna do ceticismo, não se fariam os seus ecos mais adequadamente presentes na doutrina dos ídolos - que, mesmo sem ser cética, seria, aos olhos de seu proponente, portadora de um interesse autônomo e de uma potencial atualidade filosófica nos problemas que oferece, para além de sua própria tentativa de solucioná-los? Ao menos, a filosofia baconiana se oferece, em vista desses elementos, como um capítulo à parte, importante e ainda insuficientemente pesquisado, da transmissão e da transformação do legado crítico do ceticismo antigo na modernidade. ${ }^{4}$

1 Ver Novum organum, I, §§ 101-105.

2 Defendendo a necessidade de uma nova história natural, ele afirma: “(...) Em verdade, para os que têm o propósito, não de conjecturar e adivinhar, mas de descobrir e saber, e que não pretendem imaginar macaquices e fábulas de mundos, mas tem na alma o propósito de penetrar e como que dissecar a natureza deste mundo que é o único verdadeiro, para eles tudo deve ser indagado às próprias coisas. E tal trabalho, tal pesquisa, tal viagem pelo mundo, nenhum talento (ingenium), nenhuma meditação, nenhuma argumentação pode bastar para compensá-lo ou substituí-lo, nem mesmo se todos os homens estivessem de acordo..." (Sp. I, p. 140).

3 Cf. I, § 30: "Mesmo se todos os talentos (ingenii) de todos os tempos se unissem, pondo-se de acordo e transmitindo seus trabalhos, nenhum progresso importante se poderá fazer pela via das antecipações. Pois os erros, que são radicais e intervêm na primeira digestão do espírito não são curados pelos remédios posteriores, por mais perfeitos que eles sejam...".

4 Gostaria de agradecer ao Prof. Miguel Granada, da Universidade de Barcelona, por suas úteis sugestões a uma versão prévia deste texto, bem como às observações do parecerista que o leu para publicação nesta revista. 


\section{Referências Bibliográficas}

BACON, Francis. The works of Francis Bacon. London: Longmans \& Co, 1889. 7 v. . Novum organum. Paris: Presses Universitaries de France, 1986.

. Récusation des doctrines philosophiques et autres opuscules. Paris: PUF, 1987. (Coleção Épimethé).

BOLZANI FILHO, Roberto. Ceticismo e Empirismo. Discurso, São Paulo, n. 18, p. 37-67, 1990.

CICERO. De natura deorum/Academica. London: Cambridge University Press, 1994. V. 268.

COLIE, Rosalie. Paradoxia epidemica: the renaissance tradition of paradox. Princeton: Princeton University Press, 1966.

EVA, Luiz A. Sobre o argumento cartesiano do sonho e o ceticismo moderno. Revista Latinoamericana de Filosofía, Buenos Aires, v. 27, n. 2, p. 199-225, 2001.

. A figura do filósofo: ceticismo e subjetividade em Montaigne. São Paulo: Loyola, 2006. (No prelo).

FREDE, Michael. The ancient empiricists. In: . Essays in ancient philosophy. Minesotta: University of Minesotta Press, 1987. p. 243-260.

GRANADA, M. A. Bacon and skepticism. 2006. Não publicado.

HUME, David. Tratado da natureza humana: uma tentativa de introduzir o método experimental de raciocíno nos assuntos morais. Tradução de Déborah Danowski. São Paulo: Editora UNESP, 2001. (Título original: A treatise of human nature.)

JARDINE, Lisa. Francis Bacon: discovery and the art of discourse. Cambridge: Cambridge University Press, 1974.

KANT, Emmanuel. Euvres philosophiques. Paris: Editions Gallimard, 1980. v. 1.

LE DOEUFF, Michelle. L'esperance dans la science. In: .Francis Bacon: science et méthode. Paris: Vrin, 1985. p. 37-51.

MALHERBE, Michel. Bacon's method of science. In: PELTONEN, Markku (Ed.). The Cambridge companion to Bacon. Cambridge: Cambridge University Press, 1996. p. 75-98.

MONTAIGNE, Michel de. Les essais. Paris: Presses Universitaires de France, 1999. (Col. Quadrige).

OLIVEIRA, B. J. Francis Bacon e a fundamentação da ciência como tecnologia. Belo Horizonte: Editora UFMG, 2002. (Col. Humanitas).

POPKIN, Richard. História do ceticismo de Erasmo a Espinosa. Tradução de Danilo Marcondes. Rio de Janeiro: Francisco Alves, 2000. (Título original: The history of skepticism from Erasmus to Espinosa.)

PORCHAT, Oswaldo. Empirismo e ceticismo. Discurso, São Paulo, n. 35, 2005.

PRIOR, Moody. Bacon's man of science. In: VICKERS, Brian (Ed.). Essential articles for the study of Francis Bacon. Connecticut: Archon Books, 1968. p. 348-370.

ROSSI, Paolo. Francis Bacon: from magic to science. London: Routledge \& K. Paul, 1968. 
. Bacon's idea of science. In: PELTONEN, Markku (Ed.). The Cambridge companion to Bacon. Cambridge: Cambridge University Press, 1996. p. 25-45.

SANCHEZ, Francisco. That nothing is known. Tradução de Douglas F. S. Thomson. Cambridge: Cambridge University Press, 1988. Título Original: Quod Nihil Scitur. SCHMITT, C. B. Cicero scepticus: a study of the influence of the Academica in the Renaissance. The Hague: Martinus Nijhoff, 1972.

SEXTO EMPÍRICO. Sextus Empiricus. Tradução de R. G. Bury. Harvard: Harvard University Press, 1993. 4 v.

SMITH, P. J. O ceticismo de Hume. São Paulo: Edições Loyola, 1995.

TOURNON, André. Images du pyrrhonisme selon quelques écrivains de la Renaissance. In: ISHIGAMI-IAGOLNITZER, Mitchiko (Ed.). Les humanistes et l'Antiquité Grecque. Paris: Presses du CNRS, 1989.

VILLEY, Pierre. Montaigne et François Bacon. Genève: Slatkine Reprints, 1973. 